Jurnal Hukum Mimbar Justitia

Fakultas Hukum Universitas Suryakancana

Vol. 3 No. 2 - Desember 2017 p. 234-248

ISSN: 2477-5681 (Cetak), ISSN: 2580-0906 (Online)

Open Access at: https://jurnal.unsur.ac.id/jmj

\title{
PENEGAKAN HUKUM PIDANA PROFESIONAL BERPIHAK PADA FAKTA HUKUM DAN KEADILAN
}

\author{
Rusman \\ Fakultas Hukum Universitas Suryakancana \\ E-mail: arusman159@gmail.com
}

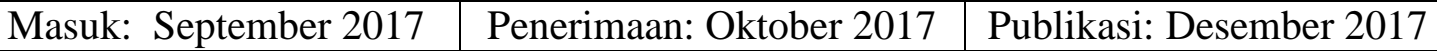

\begin{abstract}
ABSTRAK
Penegakan hukum pengadilan pidana harus berani bersikap tegas dalam proses penegakan hukum tidak boleh terbelenggu aliran legalitik normatik yang dogmatik, sudah saatnya mencari konsep yang ideal sesuai dengan rasa keadilan yang berpihak pada masyarakat (public) dan menyadari bahwa hukum dinamis mengikuti perkembangan. Penyelesaian kasus-kasus kecil tidak senantiasa harus bermuara kepengadilan, dengan menggunakan sarana penal dan memanfaatkan hukuman penjara maupun hukuman kurungan perlu dipertimbangkan lagi demi nilai keadilan. Para penyidik dituntut mempedomani ketentuan hukum materil dan formil yang berlaku penyidikan bagian dari proses penegakan hukum pidana dibutuhkan kebenaran materil, sehingga mengacu pada fakta hukum dan bukti yang didapat guna mendapatkan kepastian hukum yang bermuara pada keadilan.
\end{abstract}

Kata Kunci: Polisi, Penegakan Hukum, Professional, Keadilan

ABSTRACT

Law enforcement criminal court must dare to be assertive in the process of law enforcement should not be legalitik the chained stream normatik dogmatik, it's time to find the ideal concept in accordance with the sense of Justice in favour of society ( public) and realized that the dynamic laws of development. The small settlement of cases does not always have to be boiled down to the Court, using the means and utilizing the penal imprisonment or confinement sentence need to be considered again for the sake of the values of Justice. Investigator required material provisions of law and guided by formyl applicable investigation is part of the process of criminal law enforcement needed material, so that truth refers to legal facts and evidence obtained in order to obtain legal certainty that comes down to fairness.

Keywords: $\quad$ Police, Law Enforcement, Professional, Justice.

\section{PENDAHULUAN}

Seiring dengan perkembangan jaman, masyarakat menuntut para penegak hukum khususnya dalam hal Pelayanan Hukum dilakukan secara transparan dan akuntable sesuai dengan koridor Sistem hukum pidana. Penegakan hukum pidana sudah waktunya untuk direspon dengan 
melibatkan Aparat Penyidik, Penuntut Umum dan Pengadilan.

Sistem penegakan hukum pidana tidak senantiasa harus menggunakan sarana fenal dalam memberikan hukuman,hal ini dilatarbelakangi oleh kondisi saat ini hampir seluruh kompartement Lembaga pemasyarakat maupun rumah tahanan yang ada saat ini kondisinya over capasity, selain itu juga akhir-akhir ini para aparat penegak hukum sedang mengalami komplain dari masyaraka terutama dalam hal kinerja aparat penegak hukum di bidang penyidikan, bahkan presentasenya terus meningkat, dengan berbagai varian dari yang kurang respone dalam pelayanan sampai ke penyalahgunaan wewenang.

Sementara itu, jika mengacu pada sistem peradilan pidana sesuai tahapan dalam penegakan hukum pidana. Penyidik merupakan garda terdepan dalam penegakan hukum pidana dituntut profesional berpihak pada hukum dan keadilan, penyidikan harus menghasilkan kepastian hukum dengan Undang Undang Nomor : 8 Tahun 1981, kewenangan yang diberikan pada penyidik polri antara lain mempunyai diskresi hukum untuk menilai secara hukum terhadap perkara yang dilakukan penyidikan sebagaimana diamanatkan dalam Pasal 7 ayat (1 ) huruf j KUHAP, disebutkan penyidik sejalan dengan Pasal 16 ayat ( 1) huruf 1 Undang Undang Nomor 2 Tahun 2002 bahwa Polri dalam melaksanakan pesannya selaku penyidik berwenang mengadakan tindakan lain menurut hukum yang bertanggung jawab.Tindakan tersebut dapat dilaksanakan jika memenuhi syarat sebagai berikut :

1. Tidak bertentangan dengan suatu aturan hukum;

2. Selaras dengan kewajiban hukum yang mengharuskan tindakan tersebut dilakukan;

3. Harus patut, masuk akal, dan termasuk dalam lingkungan jabatannya;

4. Pertimbangan yang layak berdasarkan keadaan yang memaksa; dan

5. Menghormati hak asasi manusia.berwenang mengadakan tindakan lain menurut hukum yang bertanggung, dandapat tidak dilimpahkan ke tahap penuntutan atau dihentikan penyidikannya.

Namun faktanya, para penegak hukum kurang memperhatikan rasa keadilan masyarakat dalam penegakan 
hukum menjadikan hukum sebagai sarana para pihak (tersangka atau pelapor. sehingga memunculkan profesional dan proporsional sebatas parman (partisipasi teman) atau Parka (partisipasi tersangka) semestinya para penegak hukum saat ini lebih profesional dan proporsional yang didasarkan pada fakta hukum dan keadilan yang berpihak pada publik.

Pada tahap penyidikan masih ditemukan adanya Seseorang yang telah ditetapkan sebagai terlapor atau tersangka terkadang menunggu bertahun tahun untuk kejelasan dan kepastian hukum terhadap dirinya. Terkadang dalam proses penyidikan Surat pemberitahuan dimulainya penyidikan (SPDP) yang telah diterbitkan dan dikirimkan penyidik ke Jaksa Penuntut Umum, oleh Pihak Kejaksaan dikembalikan (P17) karena lambat atau tidak ada tindak lanjut penyidik dalam menindaklanjuti tahapan proses penyidikan selanjutnya pasca penerbitan dan pemberitahuan SPDP dengan melimpahkan berkas perkara sebagaimana dimaksud dalam pasal Pasal 110 ayat (1) Kuhap yang disebutkan dalam hal penyidik telah selesai melakukan penyidikan, penyidik wajib menyerahkan berkas perkara kepada penuntut umum.

Kondisi tersebut di atas, mestinya tidak perlu terjadi apabila penyidik sejak awal sudah konsekuen,melakukan proses penyidikan dengan melakukan penyelidikan awal yang fokus terhadap dugaan peristiwa yang dilaporkan memiliki bukti awal yang cukup, sehingga hasil akhir dari proses penyelidikan dengan kesimpulan penyidik menemukan dugaan telah terjadi tindak pidana sehingga dapat ditingkatkan ke penyidikan atau sebaliknya tidak ditemukan perbuatan pidana yang selanjutnya untuk kepastian hukum dihentikan penyelidikannya.

Disisi lain Hubungan Tata Cara Kerja antar aparat penegak hukum yang terbelenggu oleh adanya Ego Sektoral,antar kelembagaan Penegak hukum sebagai contoh dalam proses penyidikan masih didapat adanya berkas perkara yang bolak balik dari penyidik ke penuntut umum sebanyak 7 Kali, tindakan penuntut umum yang mengembalikan berkar perkara yang berulang ulang dengan petunjuk (P19) yang secara materil sulit atau tidak dapat dipenuhi penyidik sebaiknya untuk kepastian dan berpihak pada fakta 
hukum dan kepentingan publik Jaksa Penuntut Umum harus berani memberkan petunjuk yang tegas dan objektif yang bila sudah 3 kali Berkas perkara yang dibuat penyidik ada kekurangan sebaiknya diberikan petunjuk untuk dihentikan. Hal ini mengacu pada Hasil rapat Mahkejapol tahun 2010 yang menghasilkan Peraturan bersama Ketua Mahkamah Agung Republik Indonesia Nomor : 099/KMA/SKJ/V/2010, Menteri hukum dan Hak Azasi Manusia Republik Indonesia Nomor : M.HH 35.um.03.01Tahun 2010, Jaksa Agung Republik Indnesia Nomor : Kep 059/A/JA/ 05/2010 dan Kepala Kepolisian Republik Indonesa nomor : $\mathrm{B} / 14 / \mathrm{V} / 2010$ tentang Sinkronisasi Ketatalaksanaan Sistem peradilan Pidana dalam penegakan hukum yang berkeadilan, disebutkan dalam lampiran 8 peraturan bersama tersebut "Pengembalian perkara antara penyidik dan penuntut umum (JPU) disatu pihak penyidik merasa sudah berusaha maksimal untuk memenuhi petunjuk JPU,namun dipihak lain JPU tetap beranggapan bahwa berkas perkara tersebut belum lengkap" berdasarkan Pasal 110 yo 138 Undang-undang omor 8 Tahun 1981, Surat Edaran Jaksa
Agung nomor : 004/A/JA/02/2009 tanggal 26 Pebruari 2009, tentang meminimalisir Bolak balik perkara dan Surat Edaran Jaksa Agung Nomor : 006 /A/JA/10/2009tanggal 30 Oktober 2009, tentang penyelesaian perkara tindak pidana Umum, apabila berkar perkara sudah 3 (tiga) kali diajukan pihak penyidik dan dikembalikan olej JPU maka perkara dinyatakan tidak layak atau tidak dapat dilanjutkan dengan kata lain penyidikan harus dihentikan (SP3).

Dalam merespone tuntutan publik penyidik yang merupakan tahapan awal (garda terdepan) dalam proses penegakan hukum sesuai dengan sistem peradilan pidana perlu guna membangun figur atau profil penyidik yang profesional, penyidikan dilakukan sesuai dengan mekanisme (Standar operasional prosedur) dengan menerapkan Peraturan Kapolri Nomor : 14 Tahun 2012 tentang Manajemen penyidikan tindak pidana. Terhadap penerapan Perkap tersebut implementasinya dijabarkan:

1. Peraturan Kabareskrim nomor : 1 Tahun 2014 tentang standar prosedur Perencanaan penyidikan tindak pidana, dijabarkan menjadi 3 SOP.: 

a. Standar operasional Prosedur Perencanaan penyelidikan
b. Standar operasional Prosedur Perencanaan penyidikan
c. Standar operasional Prosedur Perencanaan anggaran penyidikan

2. Peraturan Kabareskrim nomor : 2 Tahun 2014 tentang standar prosedur Pengorganisasian penyidikan tindak pidana, berupa

a. Standar operasional Prosedur Penyidik/pembantu.

b. Standar operasional Prosedur pelaksanaan back up penyelidikan dan penyidikan tindak pidana.

3. Peraturan Kabareskrim nomor : 3 Tahun 2014 tentang standar prosedur Pelaksanaan penyidikan tindak pidana, berupa : 18 SOP ;

a. Standar operasional Prosedur penerimaan laporan polisi,

b. Standar operasional Prosedur penyelidikan tindak pidana

c. Standar operasional Prosedur pemanggilan

d. Standar operasional Prosedur penangkapan

e. Standar operasional Prosedur Penahanan f. Standar operasional Prosedur Penyitaan

g. Standar operasional Prosedur Perencanaan penyidikan

h. Standar operasional Prosedur Perencanaan penyidikan

i. Standar operasional Prosedur Perencanaan penyidikan

j. Standar operasional Prosedur Perencanaan penyidikan

k. Standar operasional Prosedur Perencanaan penyidikan

1. Standar operasional Prosedur Perencanaan penyidikan

m. Standar operasional Prosedur Perencanaan penyidikan

n. Standar operasional Prosedur Perencanaan penyidikan

o. Standar operasional Prosedur Perencanaan penyidikan

4. Peraturan Kabareskrim Nomor : 4 Tahun 2014 tentang standar prosedur Pengawasan penyidikan tindak pidana, menjadi 7 SOP.

Ketentuan ketentuan berupa Peraturan Kapolri : 14 Tahun 2012 tentang Manajemen penyidikan tindak pidanadan perkaba nomor $1,2,3$ dan 4 tersebut diatas perlu untuk disosialisasikan dan diiplementasikan keseluruh anggota Polri khususnya Penyidik dan publik, hal ini 
dimaksudkan agar dalam proses penyidikan dilakukan dengan transparan yang dapat dikontrol publik.

\section{PEMBAHASAN}

\section{Polri Selaku Penyidik}

Berdasarkan studi empiris Penulis Polri selaku penyidik dalam penegakan Hukum khususnya Hukum Pidana, Polri masih dibelenggu ajaran Teori Positivisme, yang terikat prosedural formalistik. Penegakan hukum yang bersifat formalistik saat ini sudah saatnya ditinggalkan karena publik (masyarakat) sudah menggugatnya dan dirasakan tidak adil.

Dilingkungan Akademisi (Fakar Hukum) saat ini sudah mulai mengembangkan aliran atau sistem hukum yang menganut hukum kritis maupun hukum Progresif. Polri yang merupakan garda terdepan dalam penegakan hukum sudah waktunya juga mengembangkan dan mengenalkan ajaran hukum kritis dan progresif, dalam rangka melaksanakan tugas selaku pelindung, pengayom dan pelayan masyarakat dalam penegakan hukum. Hal ini sejalan dengan telah diterapkannya Undang - Undang Nomor : 11 Tahun 2012 tentang Sistem peradilan Pidana anak.
Menurut Satjipto Raharjo, gagasan hukum Progresif muncul karena keprihatinan terhadap keadaan hukum di Indonesia. Para pengamat, termasuk pengamat internasional, sudah mengutarakannya dalam berbagai ungkapan yang negatif, seperti Sistem hukum Indonesia termasuk yang terburuk di dunia. Tidak hanya para pengamat, tetapi umumnya rakyat juga berpendapat demikian, kendatipun mereka tidak mengutarakannya sebagai suatu tuturan yang jelas, melainkan melalui pengalaman kongkrik mereka dengan hukum sehari hari, seperti kelemahan mereka saat berhadapan dengan hukum dan keunggulan orang kuat yang cendrung lolos dari hukum. Dengan demikian maka rakyat mengalami dan menjalani sehari hari, sedangkan para pengamat menuangkannya secara kontemplatif dan analitik. ${ }^{1}$

Faktanya kondisi saat ini masih ditemukan oknun penyidik yang tidak independen, dipengaruh berbagai faktor. Idealnya penyidik harus mampu independen dan transparan memposisikan diri terbebas dari Sintesa Hukum Indonesia, Genta Publising, Jogyakarta, 2009, HIm 3. 
belenggu kekuasaan/kewenangan

birokrat (termasuk unsur pimpinan dan atasan penyidik) dan pengaruh poeple power. Berpihak pada fakta hukum dan keadilan.

Hukum progresif yang dapat dipandang sebagai konsep yang sedang mencari jati diri bertolak dari realitas empirik tentang bekerjanya hukum di masyarakat berupa, ketidak puasan dan keprihatinan terhadap kinerja dan kuwalitas penegakan hukum dalam setting Indonesia akhir abad ke 20. hukum progresif dan ilmu hukum. ${ }^{2}$

Polemik mengenai Kinerja Polri yang mengutamakan Non Scientifik Investigation ini seolah menjadi akar budaya pola pemeriksaan bagi Polri yang menemui jalan buntu. Indrianto Seno Aji setuju dengan pendapat Kapolri Jendral Polisi Bambang Hendarso Danuri, bahwa yang diperlukan bagi Polri adalah pola pemeriksaan scientifik investigation yang tentunya menghindari segala bentuk Intimidasi, ancaman kekerasan pisik maupun psikologi. ${ }^{3}$

2 Dey Ravena, Makalah gagasan Konsef hukum progresif dalam penegakan hukum di Indonesia, Pasca Unisba, Bandung , 2010, HIm 2.

3 Indrianto Seno Adji, Humanisme dan Pembaharauan Penegakan Hukum, Kompas, Jakarta, 2009, HIm 35.
Dalam Proses Penegakan hukum pidana di lingkungan Polri perlu ada pembaharuan, sebagaimana dikemukakan oleh Barda Nawawi. Pembaharuan Hukum pidana juga pada hakekatnya harus merupakan perwujudan dari perubahan dan pembaharuan terhadap berbagai aspek dan kebijakan yang melatar belakangi itu.

Dengan demikian pembaharuan hukum pidana pada hakekatnya mengandung makna suatu upaya untuk melakukan reorientasi dan repormasi hukum pidana yang sesuai dengan nilai nilai sentral sosio politik socio pilosopik dan sosio cultural masyarakat Indonesia yang melandasi kebijakan sosial, kebijakan kriminal dan kebijakan penegakan hukum di Indonesia.secara singkat dapatlah dikatakan, bahwa pembaharuan hukum pidana pada hakekatnya harus ditempuh dengan pendekatan yang berorientasi pada kebijakan (policy oriented approudh) dan sekaligus pendekatan yang berorientasi pada nilai (Volue oriented approudh). ${ }^{4}$

\footnotetext{
4 Barda Nawawi Arief, Bunga Rampai Kebijakan Hukum Pidana, Citra Aditya Bakti, Bandung, 1996, HIm 30.
} 


\section{Polri Progresif Penegakan}

\section{Hukum Berwawasan Hak Azasi}

\section{Manusia.}

Polri mempunyai peran penting dalam pembaharuan hukum pidana, Polri selaku penyidik adalah wujud Kongkrik keberadaan Hukum. Disadari bahwa hukum itu bersifat abstrak baru menunjukan eksistensinya manakala Polri mulai bergerak mulai menangani masyarakat yang jadi korban atau menjadi pelaku atas tindak pidana yang terjadi.

Peran sentral Polri dalam pembaharuan hukum pidana dimungkinkan dapat mendorong terwujudnya hukum yang progresif, karena institusi Polri mempunyai jaringan struktur Sosial dari tingkat pusat (Mabes Polri) sampai dengan ditingkat desa (Bhabinkamtibmas).

Dalam pelaksanaan tugasnya Polri harus ditengah-tengah masyarakat, sosok Polri ibarat pepatah sosok atau pigur sebagai orang yang dibenci, tetapi dirindukan.

Keberadaannya dilingkungan masyarakat dalam setiap aktivitas kegiatan yang dilakukan Polri tidak boleh bersifat progresif dan responsif semata, tetapi dituntut dapat berperan ganda. Kapan sosok Polri bertindak sebagai penegak hukum yang terikat aturan normatif, legalitik, dogmatik dan legitimit dan kapan sosok Polri harus bisa bersifat humanis. Keberadaan masyarakat merupakan Patner ship yang sangat diperlukan dalam tugas pembinaan dan pemeliharaan kamtibmas maupun dalam upaya mengungkap kejahatan atau tindak pidana (awal proses penegakan hukum).

Latar belakang Polri di era pemberlakuan Undang Undang Nomor : 13 Tahun 1961, tentang Undang Undang Pokok Kepolisian Negara Ripublik Indonesia, secara struktural bidang Operasional maupun pembinaan Karir Institusi Polri berada di bawah Panglima ABRI (saat ini Panglima TNI) Sehingga tugas Polri juga menganut sistem Komando, guna mewujudkan loyalitas dan jiwa korp kesatuan. Bahkan Polri juga tundak pada Peradilan Militer dan guna memupuk moril dan disiplin Polri diberlakukan juga Kitab Undang - undang Hukum Disiplin Tentara (KUHDT).

Dalam salah satu Pasal kitab Undang-undang disiplin tentara tersebut, disebutkan seorang Prajurit dilarang untuk protes atau keberatan terhadap perintah yang diberikan, protes atau keberatan tersebut dapat diajukan 
setelah 14 hari sejak perintah diberikan.

Pemberlakuan Kitab Undang-undang

Disiplin Tentara ini menjadi salah satu penyebab Polri tidak memiliki independensi bahkan tidak profesional dalam penegakan hukum (diskriminasi). Kredibilitas penyidik sangat tergantung pada atasan penyidik. Budaya mohon petunjuk kepada Atasan, juga melekat di Institusi Polri.

Adanya budaya mohon petunjuk yang sering dilakukan tataran pelaksana (Penyidik maupun penyidik pembantu) telah mengkerdilkan citra penegakan hukum khususnya tataran penyidik, sehingga bila ada komplin dari pencari keadilan para pelaksana penyidik mempunyai jawaban "maaf saya hanya melaksanakan tugas perintah Komandan”. Hal ini terjadi karena Polri bagian dari ABRI yang menerapkan sistem Komando. Tetapi disisi lain kemampuan wawasan hukum para penyidik Polri sangat minim, kemampuan penguasaan hukum hanya didasarkan pengalaman empiris semata, sedikit sekali penyidik yang menguasai hukum secara teoritis yang menguasai teori - teori hukum maupun asas - asas hukum. Kemampuan wawasan hukum berkisar pada prosedural yang legalitik didasarkan ajaran dogmatik dari para senior penyidik.

Berpijak dari Peraturan Pemerintah Nomor : 58 Tahun 2010, dijelaskan untuk persyaratan penyidik adalah berpendidikan minimal Strata satu (S1) dan pangkat Inspektur Polisi dua (IPDA), ketentuan ini berlaku mulai tahun 2015. Namun faktanya Penyidik Polri yang bertugas di Polsek Rulel umumnya masih berpendidikan setara SMA. Hal ini bilamana Pimpinan Kesatuan Polri tidak segera melakukan trobosan Kreatif bekerja sama dengan Perguruan tinggi pada saat berlaku efektif terhadap Peraturan Pemerintah nomor : 58 Tahun 2010 tentang Perubahan atas Peraturan Pemerintah

Nomor : 27 Tahun 1983 tentang Pedoman pelaksanaan Kitab Undang Undang Hukum Acara Pidana, dapat menjadi sandungan dalam penegakan hukum.

Kualitas penegakan hukum yang dituntut masyarakat, saat ini bukan sekadar kualitas moral, tetapi tetapi terutama kualitas penegakan hukum secara materil atau substansial seperti terungkap dalam beberapa isu dimasyarakat antara lain,

a. Adanya perlindungan Hak Azasi Manusia; 
b. Tegaknya nilai kebenaran, keadilan, dan kepercayaan antar sesama; (tidak adanya penyalahgunaan kekuasaan atau kewenangan;

c. Bersih dari praktek favoritisme pilih kasih, KKN, dan mafia peradilan;

d. Terwujudnya

kekuasaan kehakiman atau penegakan hukum yang merdeka,dan tegaknya kode etik atau kode profesi. Adanya pemerintahan yang bersih. ${ }^{5}$

Faktor yang juga akan menentukan kualitas pelayanan dalam penegakan hukum, ialah kualitas polri karena terdapat kaitan yang erat antara tingkat pendidikan dan kinerja Polri. Polri yang berpendidikan akademi lebih memiliki kepekaan terhadap rakyat, kemampuan berkomunikasi dan cara bertindak pada umumnya. Pendidikan akademi diharapkan mendukung Polri menangka perspektif pekerjaannya, peran Polri dalam masyarakat serta persoalan -persoalan etika dan moral yang dihadapi oleh Polri. Cara singkat,

5 Barda Nawawi Arief, Masalah penegakan hukum dan kebijakan hukum pidana dalam penanggulangan kejahatan, Kencana, Jakarta 2008. HIm 19.
Polri dengan pendidikan akademi cenrung lebih adil, jujur dan efektif. ${ }^{6}$

\section{Polri dan Hak Asasi Manusia}

Globalisasi (era kesejagatan) secara makro melahirkan tiga (3) tuntutan mendasar, yaitu HAM, demokratisasi, dan ekologi. Ketiga tuntutan tersebut sangat esensial dengan pekerjaan Kepolisian untuk mempersiapkan Sistem, Organisasi, dan Manajerialnya. ${ }^{7}$

Sejalan dengan tugas Polri selaku penyidik terhadap tindak pidana Teroris dalam proses penegakan hukum pidana harus memperhatikan ketiga hal tersebut. Berkaitan dengan HAM, menurut Artijo Al Korstar (Hakim Agung di era tahun 2000) Hak Azasi Manusia merupakan hak kodrati, berasal dari Tuhan. Tiada seorang pun atau kekuasaan apapun yang boleh memanipulasi apalagi merampas hakhak dasar manusia.

Jika dikaitkan dengan Undangundang nomor : 39 Tahun 1999 merupakan pelanggaran HAM. Warga

Satjipto Rahardjo, Polri sipil, dalam perubahan sosial di Indonesia, Kompas, Jakarta HIm 62.

7 Anton Tabah,Membangun Polri yang kuat ( belajar dari macan - macan Asia ), PT Sumber Sewu Lestari, Jakarta, 2002, HIm 87. 
negara RI (para tersangka pengeroyokan dan penganiayan) yang sedang menjalani Proses hukum mestinya mendapat perlindungan hukum dari Negara. Tetapi ini sebaliknya. Hal seperti ini tidak boleh terjadi lagi. Menjadi tugas Polri bersama komponen bangsa lainnya serta dukungan penuh dari masyarakat untuk menghentikan praktek-praktek yang menurunkan Citra nama baik Bangsa dan Negara dimata dunia Internasional.

Pengembangan profesional dalam kontek sistem peradilan pidana harus mendapat perhatian yang serius. Banyak putusan - putusan pengadilan atau jalannya pengadilan tidak lagi memberi perlindungan hukum kepada terdakwa atau tidak memenuhi rasa keadilan masyarakat disebabkan lemahnya kemampuan profesionalisme aparat dalam menemukan legal spirit dari suatu undang-undang dalam praktek penegakan hukum. Pada saat ini masyarakat berpandangan sangat buruk terhadap kinerja sistem peradilan pidana. $^{8}$

\section{Transparansi penyidikan tindak pidana}

8 Edi Setiadi, Bunga Rampai Hukum Pidana, FH Unisba, Bandung 2004, HIm 258.
Polri tampaknya belum sepenuhnya dapat melakukan penegakan hukum secara profesional, masih ditemukan adanya komplain dari pelapor (korban kejahatan) atau pihak terlapor (tersangka atau kuasanya) atas tersangka. Kondisi ini sebenarnya sudah direspone jajaran pimpinan Polri antara lain dalam program grand strategi membangun Polri ke depan, dengan digulirkan Program Quiks win (Percepatan pelayanan Polri).

Program Quick Wins adalah suatu program percepatan pelayanan Polri kepada masyarakat dalam membangun kepercayaan masyarakat (Trust building) yang berati Polri harus mudah ditemui, dan segera merespon setiap laporan maupun pengaduan dan memberikan pertolongan terhadap keluhan-keluhan masyarakat.

Quick wins ini merupakan program unggulan Polri, khususnya dalam bidang penegakan hukum dilaksanakan program Transparansi penyidikan, siapapun yang sedang menjalani proses hukum ditingkat penyidikan (pelapor, terlapor dan advokat atau keluarganya) berhak dan dapat memonitor dan mengetahui perkembangan perkaranya melalui 
penyidik yang menangani perkara tersebut, program tersebut implementasinya dengan melaksanakan

a. Quick respone, percepatan pelayanan Polri yang prima kepada masyarakat di sentrasentra pelayanan Kepolisian yaitu kecepatan merespone laporan dan kecepatan bertindak.

b. Di bidang penegakan hukum, nmelaksanakan Transpransi penyidikan, dengan memberikan SP2HP (surat pemberitahuan perkembangan hasil penyidkan) kepada para pelapor, transparansi proses penyidikan melalui pelayanan SP2HP oleh penyidik Reserse kriminal, Narkoba, dan Lantas yang intinya harus tahu siapa penyidiknya, kapan ditangani dan kapan penyelesaiannya. Ini merupakan bagian dari proses penegakan hukum pidana oleh Penyidik Polri.

c. Disusunnya standar operasional prsedur dalam proses penyidikan dengan terukur. Kedalam peraturan Kapolri nomor 12 Tahun 2009 Tentang Pengawasan dan pengendalian penanganan perkara pidana di lingkungan Polri, yang telah diubah dengan Peraturan Kapolri nomor : 14 Tahun 2012 Tentang Manajemen Penyidikan tindak pidana. Dan dijabarakan kedalam Standar operasional prosedur dalam penyidikan tindak pidana berupa Peraturan Kabareskrim Polri nomor 1.2,3 dan 4 Tahun 2014. sehingga perkap nomor; 14 Tahun 2012 tentang Manajemen penyidikan tindak pidana implementasinya dijabarkan menjadi 30 SOP yang menjadi acuan dalam proses penyidikan tindak pidana di lingkungan Polri.

d. Transparansi dalam rekruitmen personil, bagaimana penyelenggaraan rekruitmen Polri yang bersih dan bebas kolusi korupsi dan nepotisme. Serta sejak awal pendidikan sudah dididik langsung mantra penyidik di Pusdik Reserse Megamendung. Di bidang penegakan hukum khususnya dalam hal penyidikan program Transparansi di bidang penyidikan dalam upaya meningkatkan pelayanan dalam penegakan hukum meliputi : 
a. Surat pemberitahuan hasil penyelidikan dan atau penyidikan;

b. Desk telpone (petugas penerima pengaduan perkembangan hasil penyelidikan dan penyidikan melalui telepone);

c. Website, pengadu dapat menanyakan perkembangan asil penyelidikan dan penyidikan melalui website;

d. SMS, pengadu menanyakan perkembangan hasil penyelidikan dan penyidikan melalui handpone dengan SMS;

e. Gelar perkara, pengadu menyampaikan keluhannya dalam forum gelar perkara. ${ }^{9}$

Masuknya moralitas menjadi isi minuman hukum menurut Hart merupakan hal yang wajar, bahkan relevan. Menurut Hart terdapat berbagai fakta Natural dalam manusia yang membuat prinsip moral menjadi penting atau tidak dapat diabaikan dalam pertimbangan hukum. Fakta natural itu antara lain seperti kenyataan bahwa manusia rentan dan mudah terancam bahaya; menusia kurang lebih sama dalam hal kemampuan intelektual dan

9 Susno Duadji, Pedoman pelaksanaan quick wins bidang transparansi penyidikan, Bareskrim, Jakartan, 2009 HIm 6. phisik; manusia tidak egoistis tetapi juga memiliki kamauan baik (Good will) yang terbatas terhadap yang lain; manusia memiliki keterbatasan untuk melihat kedepan serta mengontrol dirinya: dan akhirnya, sumber daya yang dibutuhkan manusia relatif terbatas. Fakta ini merupakan keterbatasan yang suka atau tidak suka dialami manusia yang dapat menimbulkan masalah sosial berupa ancaman terhadap manusia itu sendiri. ${ }^{10}$

Peran Polri sebagai aparat penegak hukum terhadap tindak pidana terorisme seharusnya mengedepankan Preventif (kebijakan non Penal). Tindakan Represif (kebijakan penal) baru dilakukan bila terjadi kegagalan dalam tataran kebijakan non Penal. Hal ini guna memperkecil tindakan yang dapat dikatagorikan memunculkan pelanggaran Hak Azasi Manusia. Tertembaknya pelaku terorisme oleh Detasemen 88 anti teror, seperti yang terjadi pada hari minggu tanggal 18 Maret 2012 di Bali yang mengakibatkan meninggalnya 2 Orang terduga terorisme, ini menunjukan bahwa tindakan represif sangat berisiko baik

10 Andre Ata Ujan, Filsafat Hukum, membangun hukum membela keadilan, Kanisius, Jogyakarta, 2009, HIm 155. 
terhadap aparat maupun pelaku bahkan masyarakat disekitar lokasi tersebut.

Penyidikan adalah serangkaian proses yang memakan waktu panjang yang harus dilakukan oleh Penyidik (Polri) merupakan langkah aplikasi pengetahuan tentang dua wilayah hukum, yaitu wilayah hukum normatif dan wilayah hukum yang progresid sosiologis. Wilayah hukum yang normatif diartikan bahwa Polri yang menyidik itu hanya mengikuti serangkaian peraturan perundangundangan. Serangkaian aturan hukum atau perundang-undangan itulah yang menjadi target atau ukuran. Wilayah hukum progresif mensinkronkan antara kehendak moralitas dengan legalitas hukum normatif. ${ }^{11}$

Penegakan hukum oleh Polri selaku penyidik terhadap tindak pidana pada hakekatnya adalah pembuktian bagaimana agar seseorang atau kelompok tersebut dengan bukti yang ada dapat menimbulkan keyakinan Hakim disidang pengadilan, sehingga hakim dapat menjatuhakan hukuman yang adil dengan mempertimbangkan

11 Hartono, Penydikan dan penegakan hukum pidana, melalui hukum progresif, Sinar Grafika,Ngaliyan Sudan, 2010 hlm 36. kepentingan publik (masyarakat) dan kepentingan terdakwa.

Dibidang penegakan hukum Polri berperan selaku penyidik bagian dari sub sistem peradilan pidana. Implementasinya dalam proses penyidikan penyidik dituntuntut profesional, menurut penulis profesional minimal memiliki kemampuan :

a. Menguasai dan memiliki pemahaman hukum dan perundangan terkait dengan tindak pidana yang sedang dilakukan penyidikan.

Knowledge of law).

b. Memiliki keterampilan, dengan menguasai dan memahami tehnis dan taktis penyidikan (Skill).

c. Memiliki komitment menyadari bahwa penegakan hukum (penyidik) diperlukan keberanian, menghilangkan ego sektoral, bahwa penegakan hukum dituntut indepenent berpihak pada fakta hukum dan keadilan.

\section{PENUTUP}

Adanya Konsep Hukum Acara Pidana Nasional (RUU HAP Nasional) dengan mencantumkan adanya pembatasan waktu paling lama 7 (tujuh) 
hari ini dalam proses pembuatan berita acara dan resume bagi penyidik, memberikan suatu gambaran kinerja proses penegakan hukum yang dilakukan oleh Polri harus dilaksanakan secara profesional. Sosok Polri yang butuhkan masyarakat saat ini adalah sosok Polri yang progresif terhadap masyarakat karena kepercayaan masyarakat mempengaruhi proses penegakan hukum dari mulai konsep dan pemikiran dalam melakukan penegakan hukum dilaksanakan secara Progresif dengan mengadopsi tuntutan publik yang dilakukan secarahumanis guna meningkatkan citra penegakan hukum di Indonesia dewasa ini.Salah satu kelemahan dalam proses penegakan hukum khususnya yang dilakukan oleh Penyidik Polri karena faktor kualitas sumber daya manusia, tingkat pengetahuan intelektual Penyidik dan penyidik pembantu.

\section{DAFTAR PUSTAKA}

Andre Ata Ujan, Filsafat Hukum, membangun hukum membela keadilan, Kanisius, Jogyakarta, 2009.

Anton Tabah,Membangun Polri yang kuat (belajar dari macan - macan Asia), PT Sumber Sewu Lestari, Jakarta
Barda Nawawi Arief, Bunga Rampai Kebijakan Hukum Pidana, Citra Aditya Bakti, Bandung, 1996.

\section{Masalah}

penegakan hukum dan kebijakan hukum pidana dalam penanggulangan kejahatan , Kencana, Jakarta 2008.

Dey Ravena, Makalah gagasan Konsef hukum progresif dalam penegakan hukum di Indonesia, Pasca Unisba, Bandung, 2010.

Hartono, Penydikan dan penegakan hukum pidana, melalui hukum progresif, Sinar Grafika,Ngaliyan Sudan, 2010.

Indrianto Seno Adji, Humanisme dan Pembaharauan Penegakan Hukum, Kompas, Jakarta, 2009.

Satjipto Rahardjo, Hukum Progresif, Sebuah Sintesa Hukum Indonesia, Genta Publising, Jogyakarta, 2009.

Polri sipil, dalam perubahan sosial di Indonesia, Kompas, Jakarta.

Susno Duadji, Pedoman pelaksanaan quick wins bidang transparansi penyidikan, Bareskrim, Jakartan, 2009. 